Актуальні проблеми розвитку економіки регіону. Вип 16. T.2

5. Chaianov, A.B. Peasant economy. Moscow, Economics. 1989.

6. Ryvkina, R.V. Lifestyle of the rural population (methodology, methods and results of studying the socio-economic aspects of life). Novosibirsk, Nauka, 1979.

7. Tulush, L.D., and O.Y. Grishchenko. "Transformation of highly commercial households into business entities: tax and budgetary aspects." Economics of agro-industrial complex, no.1, 2018, pp. 40-52.

8. Rybak, Y. Y. "Agricultural service cooperation as a means of development of personal peasant farms." Economics of agro-industrial complex, no.9, 2014, pp. 103-107.

9. Shepel, I.V. "Self-employment of rural residents in personal households." Science and economics, issue 2, 2015, pp. 62-68.

10. Demchak, I.M. Methodical approaches to assessing the activities of personal farms. Kyiv: Ukragropromproductivnist, 2018.

\title{
УДКЗ378.1
}

doi: 10.15330/apred.2.16.126-138

\section{ЗРУШЕННЯ У ГЛОБАЛЬНОМУ ОСВІТНЬОМУ ПРОСТОРІ В СУЧАСНИХ УМОВАХ (РЕГІОНАЛЬНИЙ ТА НАЦІОНАЛЬНИЙ ВИМІРИ)}

\author{
Маріупольський державний університет, \\ Міністерство освіти і науки України, \\ кафедра економіки та міжнародних економічних \\ відносин, \\ просп. Будівельників, 129а, м.Маріуполь, \\ 87400, Україна, \\ тел.: 0629587553, \\ e-mail: ie@mdu.in.ua
}

Анотація. Стаття присвячена дослідженню сучасних глобальних процесів, які суттєво впливають на трансформацію у системі вищої освіти. Інтернаціоналізація стала не тільки невід'ємною частиною безперервного процесу змін у вищій освіті, фактично процеси інтернаціоналізації вищої освіти стали важливою детермінантою розвитку та реформування вищої школи. В умовах глобальних трансформацій сучасного світу міжнародна співпраця стала важливим показником розвитку освіти, а самі університети стають глобальними установами, вплив яких на формування конкурентних переваг національної соціально-економічної системи постійно посилюється.

Оскільки в умовах інтернаціоналізації вищої освіти докорінно змінюється місце та роль університетів, існує потреба дослідження та виявлення відповідних тенденцій, що враховують трансформації, що відбуваються на національному, регіональному та глобальному рівнях і які матимуть відповідний вплив на подальший розвиток процесів інтернаціоналізації вищої освіти у майбутньому, що визначило мету наукової статті.

Для досягнення мети використано загальнонаукові та спеціальні методи дослідження, а саме: методи аналізу, абстрагування та синтезу (при дослідженні тенденцій, що враховують як внутрішні трансформації, так і глобальні зміни, і які визначають розвиток вищої освіти); методи класифікації та системного узагальнення (для систематизації структурних трансформацій, що відбуваються на освітніх послуг); статистичні методи (для кількісної оцінки трансформацій, що відбуваються у глобальному освітньому просторі в сучасних умовах).

Доведено, що врахування змін, що відбуваються у вищій освіті, передбачають розширений розвиток міжнародних науково-дослідницьких та освітніх програм і проектів, створення розгалуженої мережі між університетської співпраці одночасно із урахуванням та збереженням кращих національних традицій і культурних цінностей. 
Актуальні проблеми розвитку економіки регіону. Вип 16. T.2

Ключові слова: глобалізація, інтернаціоналізація вищої освіти, вища освіта

\title{
DISPLACEMENTS IN THE GLOBAL EDUCATIONAL SPACE IN Monovski O.S. CONDITIONS (REGIONAL AND NATIONAL DIMENSIONS)
}

\author{
Mariupol State University, \\ Ministry of Education and Science of Ukraine, \\ Department of Economics and International \\ Economic Relations, \\ ave. Budivelnykiv, 129a, Mariupol, \\ 87400, Ukraine, \\ tel.: 0629587553, \\ e-mail: ie@mdu.in.ua
}

\begin{abstract}
The article is devoted to the study of modern global processes that significantly affect the transformation of the higher education system. Internationalization has become not only an integral part of the continuous process of change in higher education, in fact, the processes of internationalization of higher education have become an important determinant of the development and reform of higher education. In the context of global transformations of the modern world, international cooperation has become an important indicator of educational development, and universities themselves are becoming global institutions, whose influence on the formation of competitive advantages of the national socio-economic system is constantly increasing.

As the internationalization of higher education radically changes the place and role of universities, there is a need to study and identify relevant trends that take into account the transformations taking place at the national, regional and global levels and determined the purpose of the scientific article.

To achieve this goal, general and special research methods were used, namely: methods of analysis, abstraction and synthesis (in the study of trends that take into account both internal transformations and global changes, and which determine the development of higher education); methods of classification and system generalization (for systematization of structural transformations occurring in educational services); statistical methods (to quantify the transformations taking place in the global educational space in modern conditions).

It is proved that taking into account the changes taking place in higher education involves the expanded development of international research and educational programs and projects, the creation of an extensive network between university cooperation while taking into account and preserving the best national traditions and cultural values.
\end{abstract}

Key words: globalization, internationalization of higher education, higher education.

Вступ. Глобальні процеси, що поглиблюються у світовому господарстві, постійно впливають на трансформацію вищої освіти. 3 іншого боку, інтернаціоналізації вищої освіти стала важливим фактором подальшого розвитку глобальних процесів. За таких умов змінюється місце та роль університетів, посилюється конвергенції національних освітніх систем, що потребує відповідних досліджень особливостей розвитку інтернаціоналізації вищої освіти у країнах та регіонах світу, вивчення процесів міжнародної мобільності студентів із урахуванням геополітичних та геоекономічних факторів впливу, інституційних драйверів тощо.

Інтернаціоналізація як об'єктивний процес стала невід'ємною частиною змін у вищій освіті, важливою детермінантою іiі розвитку та реформування. Глобалізація стала фундаментальнішим викликом для вищої освіти за всю історію ії розвитку (П. Скотт, Д. Деланті[6,24]), відповідно, саме глобалізація сплинула на розвиток як національних, так і світової системи вищої освіти. За таких умов вища освіта набула 
Актуальні проблеми розвитку економіки регіону. Вип 16. T.2

міжнародного виміру (Ф.Дж. Альтбах, Л.Рамблей Л.Рейзберг [2,3]). Розвиток інтернаціоналізації як концепції в ретроспективному аспекті, визначення її моделей та основних тенденцій представлено у роботах Х.де Віта, Ф. Хантер, Л.Ховард [13]. Однак інтернаціоналізація має різний вплив на характер розвитку національних систем вищої освіти (Е.Егрон-Полак, Р.Хадсон [107]), що вплинуло на появу й скептичного ставленням до інтернаціоналізації вищої освіти (Г. Роадс [22]).

Аналіз наукових джерел дозволяє дійти висновку про взаємозв'язок та взаємозалежність процесів інтернаціоналізацій та глобалізації, при цьому, інтернаціоналізація - це динамічний процес, а не певний набір або сукупність ізольованих заходів, що характеризують відповідні явища [18]. Можна виділити два основні підходи визначення інтернаціоналізації вищої освіти: по-перше, визначення процесів в освітній сфері, які пов'язані із перетином кордонів (знань, мобільність та ін.), а з іншого боку, процеси інтернаціоналізації визначають загальний напрямок змін та цілеспрямовану діяльність у напрямку більшої «інтернаціональності» [25, с.182].

У попередніх дослідженнях автора виділено та проаналізовано характер розвитку сфери вищої світи як суб'єкта глобального освітнього простору [30]; досліджено динамічні зрушення та визначено регіональний розподіл міжнародної мобільності студентів [12], розвинуто методичний інструментарій кількісної оцінки рівня розвитку процесів інтернаціоналізації вищої освіти [31].

Постановка завдання. Метою наукової статті $€$ виявлення тенденцій, що враховують трансформації, які відбуваються на національному, регіональному та глобальному рівнях і які матимуть відповідний вплив на подальший розвиток процесів інтернаціоналізації вищої освіти у майбутньому.

У роботі використано загальнонаукові та спеціальні методи дослідження, а саме: методи аналізу, абстрагування та синтезу (при дослідженні тенденцій, що враховують як внутрішні трансформації, так і глобальні зміни, і які визначають розвиток вищої освіти); методи класифікації та системного узагальнення (для систематизації структурних трансформацій, що відбуваються на освітніх послуг); статистичні методи (для кількісної оцінки трансформацій, що відбуваються у глобальному освітньому просторі в сучасних умовах).

Результати. Сучасні глобальні процеси суттєво вплинули на трансформацію у системі вищої освіти. Аналіз досліджень [1,5,27,28] дозволяє проаналізувати та визначити основні тенденції, що враховують як внутрішні трансформації, так i глобальні зміни, і які визначатимуть характер розвитку інтернаціоналізації вищої освіти.

Світовий валовий показник охоплення населення вищою освітою в цілому у світовому господарстві зріс з 14\% у 1993 році до 38\% у 2017 році (середньою за цей же період зріс з 55\% у 1993 році до 77\% у 2017 році) [29]. Основний вплив на глобальне зростання охоплення вищою освітою протягом останнього десятиліття забезпечили Аргентина, Бразилія, Китай, Індія, Індонезія, Російська Федерація, Саудівська Аравія, Південна Африка тощо. Якщо у 2005 році майже кожен шостий у світі у віці 25-34 років, хто мав вищу освіту, припадав на США, то з 2013 року на першу позицію вийшов Китай (17\%), на США та Індію припадає по 14\%. Збереження цієї тенденції забезпечить домінування Китаю та Індії серед країн G20 за показником молодих людей віком 25-34 років з вищою освітою прогнозні очікування у 2030 році становлять 300 мільйонів осіб, тоді як країни Європейського Союзу та США разом становлять менше чверті[9].

У наслідок поступового розширення економіки знань прогнозні очікування щодо охоплення населення світу освітою передбачають, що рівень охоплення початковою освітою населення у масштабах всього світового господарства становитиме 91\%. 
Актуальні проблеми розвитку економіки регіону. Вип 16. T.2

Більше половини населення світу (55\%) матиме середню/ вищу освіту, а від так розрив у знаннях між розвиненими та країнами, що розвиваються, буде скорочуватись[11].

За прогнозними оцінками кількість молодих людей з вищою освітою (25-34 роки) в країнах OECP i G20 буде постійно зростати. Основну частину приросту забезпечать такі країни, як Китай та Індія, вклад яких у формування робочої сили із вищою освітою у галузі математичних, технічних, природничих наук до 2030 року оцінюється у 60\% від загальної обсягу робочої сили країн G20.

Зростання середнього класу посилює попит на якісну освіту На початок 2017 року у світовому господарстві середній клас нараховував близько 3,2 млрд.осіб [17,c.11-15]. Щороку до середнього класу приєднуються близько 140 млн. щорічно - це дозволить очікувати того, що к 2020 року половина населення світу буде відноситись до середнього класу. I якщо у розвинутих країнах приріст середнього класу відбувається повільно, то серед країн, що розвиваються (табл.1.), цей приріст щороку посилюється, в першу чергу в Китаї та Індії, де кількісне оцінювання середнього класу становить, відповідно, 350 млн. та 380 млн. Як результат, до 2030 року 2/3 світового середнього класу буде припадати саме на азійські країни.

Розподіл середнього класу у світі (регіональний аспект)

Таблиия 1

Table 1

Distribution of the middle class in the world (regional aspect)

\begin{tabular}{|l|r|r|r|r|r|r|r|r|}
\hline \multirow{2}{*}{ Регіон } & \multicolumn{2}{|c|}{2015} & \multicolumn{2}{c|}{2020} & \multicolumn{2}{c|}{2025} & \multicolumn{2}{|c|}{2030} \\
\cline { 2 - 9 } & Млн.осіб & \% & Млн.осіб & $\%$ & Млн.осіб & $\%$ & Млн.осіб & $\%$ \\
\hline $\begin{array}{l}\text { Північна } \\
\text { Америка }\end{array}$ & 335 & 11 & 344 & 9 & 350 & 8 & 354 & 7 \\
\hline Свропа & 724 & 24 & 736 & 20 & 738 & 16 & 733 & 14 \\
\hline $\begin{array}{l}\text { Центральна та } \\
\text { Південна } \\
\text { Америка }\end{array}$ & 285 & 9 & 303 & 8 & 321 & 7 & 335 & 6 \\
\hline $\begin{array}{l}\text { Азійсько- } \\
\text { тихоокеанський } \\
\text { регіон }\end{array}$ & 1380 & 46 & 2023 & 54 & 2784 & 60 & 3492 & 65 \\
\hline Суб-Сахара & 114 & 4 & 132 & 4 & 166 & 4 & 212 & 4 \\
\hline $\begin{array}{l}\text { Близький Схід } \\
\text { та Північна } \\
\text { Африка }\end{array}$ & 192 & 6 & 228 & 6 & 258 & 6 & 285 & 5 \\
\hline Світ у цілому & 3030 & 100 & 3766 & 100 & 4617 & 100 & 5412 & 100 \\
\hline
\end{tabular}

Джерело: [ 17 ]

Зростання середнього класу пов'язане, в першу чергу, із міграцією від сільських до міських районів, а по друге, домогосподарства середнього класу мають тенденцію більше інвестувати освіту своїх дітей. У розвинених країнах споживання середнього класу щороку зростає від 0,5 до 1 \% на рік, тоді як у країнах, що розвиваються, споживання зростає набагато швидше - від 6 до 10\%. Таким чином, зростання обсягів споживання середнього класу стає відповідним драйвером розвитку та зростання.

Основний приріст населення світу, а також безпосередньо середнього класу, забезпечують Китай, Індія, на долю яких припадатиме $90 \%$ середнього класу. Це вимагатиме відповідної реакції з боку вищої школи, яка має задовольнити більш вимогливих споживачів освітніх послуг. Крім того, зростання тривалості життя, розвиток медичних технологій впливатимуть на збільшення кількості нетрадиційних 
студентів більш старшого віку, а від так, попит на нові програми перепідготовки, повторне навчання, підвищення кваліфікації тощо буде з кожним роком посилюватись.

Важливо підкреслити, що підвищення тривалості життя, зростання кількості нетрадиційних студентів віком впливають на те, що участь у глобальному ринку праці поступово знижується, особливо критичними ці процеси є серед людей молодого віку, фактично п'ята частина молоді протягом останніх десяти років залишається у стані і не зайняті, і не навчаються. Ця ситуація є незміною починаючи 32008 року, коли цей показник становив 22\%, у 2018 році він становив 21\%), що посилює ризики соціального та економічного виключення молоді у забезпеченні сталого розвитку. Слід зазначити, що ємність глобального ринку праці становить 3,5 млрд.осіб, 3 яких зайнятими є 3,3 млрд.осіб. Рівень глобального безробіття в світі оцінюється в $11,8 \%[29]$.

Структурні трансформації, що відбуваються на ринку праці, поширення процесів автоматизації виробничих процесів, активне впровадження робототехніки посилюють вплив на структурні трансформації, що відбуваються у розвитку вищої освіти. Суттєво зменшується попит на професії, які пов'язані із рутинною роботою, яку можна відтворити відповідними алгоритмами, у той час як відбувається постійне зростання попиту на робочу силу, що відрізняється навичками критичного експертного мислення, навичками комунікацій тощо. Найбільш складними для автоматизації залишаються роботи, що не потребують наявності вищої освіти, тоді як професії, опанування якими потребує університетської освіти, найлегше автоматизуються, а від так, у майбутньому саме вони більш ймовірно зникнуть на ранку праці. У світі зростає попит на передові навички, які потребують відповідної освіти, у першу чергу, STEM освіту (S (science) природничі науки, T (technology) - технологія, E (engineering) - інженерія, M (mathematics) - математичні науки). Навички, які формуються під час опанування STEM освітою $є$ критично важливими для розвитку інновацій, забезпечення технологічного прогресу та економічного зростання.

За останніми результатами близько третини усіх іноземних студентів, що навчаються в університетах ОЕСР, обирають спеціальності, пов'язані із STEM освітою [8,c.220], у тому числі інженерні науки, виробництво та будівництво (17\%); природничі науки, математика та статистика (10\%); інформаційно-комунікаційні технології (6\%). Слід зазначити, що вже сьогодні по різним країнам спостерігається незбалансований розподіл випускників за галузями вищої освіти. Так, в країнах ОЕСР випускників гуманітарних, соціальних наук, юридичних та освіти втричі більше, ніж тих випускників, що вивчали природничі, математичні, технічні науки.

Існує достатньо великий розрив у STEM освіти серед країн. Серед країн, що забезпечують значний обсяг випускників інженерних спеціальностей слід виділити Китай (32\%), Сінгапур (28\%), Гану (31\%), Колумбію (18\%). У цілому, у світовому господарстві загальна кількість бакалаврів, що мають завершену STEM освіту, становить понад 7,5 млн., домінуюча частина з яких припадає на Індію (25\%) та Китай (22\%), країни СС (12\%), США (10\%). Слід зазначити, що темпи зростання кількості отриманих дипломів саме по цим галузям у Китаї $є$ значно більшими, ніж у багатьох розвинутих країнах, в 3,5 рази [23]. У той же час слід зазначити, що із урахуванням можливостей переваг міжнародної мобільності, що дозволяє не тільки отримати якісну освіту, а й майбутнє робоче місце, іноземні студенти не тільки обирають для отримання STEM світи університети США, Великобританії, Австралії, Франції тощо, а й залишаються потім у цих країнах.

Поширення цифрової економіки посилює попит на вкрай потрібних для національних господарств фахівців із IT навичками. Однак, університети не спроможні задовольнити у повній мірі потреби роботодавців. За даними американського бюро 
трудової статистики пропозиція робочих місць, пов'язаних із комп'ютерною галуззю, становитимуть понад 1,4 млн. У той же час, вища школа спроможна випустити близько 400 тисяч випускників із необхідними навичками [16]. I це при тому, що працівники 3 IT технологій мають рівень заробітної плати на $74 \%$ вищий, ніж у середньостатистичного робітника.

Не менш важливою тенденцію, що має значний вплив на розвиток системи вищої освіти стає поглиблення розриву між вимогами роботодавців та університетським досвідом. Це вимагає збільшення навичок студентів, спроможних до швидкої адаптації до змін, які будуть відбуватись на робочих місцях, куди прийдуть випускники університетів. Крім того, із поширенням цифрової економіки зростає потреба у цифровій грамотності та критичному мисленні. Важливою дилемою для освіти стає питання відповідності та доповнюваності професійних навичок і штучного інтелекту. Відповідно, завдання університетів, використовуючи змішані форми навчання, забезпечити саме таку підготовку студентів, що дозволить останнім швидко адаптуватись до нових умов, спроможних навчатись протягом усього життя. Про невідповідність потреб роботодавців та навичок працівників наявно демонструють наступні дані. За інформацією Бюро трудової статистики США рівень відкритих вакансій складає понад 7 млн. Кількість найманих працівників становить 5,9 млн.осіб.[26].

У світі спостерігається поступове скорочення фінансування діяльності університетів 3 боку держави. Однак недостатнє інвестування освіти веде до неоптимальних темпів зростання та розвитку, оскільки саме людський капітал відіграє центральну роль у зростанні та розвитку [20]. Певною мірою можна казати, що рентабельність інвестицій у вищу освіту буде визначатись для здобувача вищої освіти: потенційним розміром заробітної плати, рівень якої буде вище, ніж у іншого робітника без вищої освіти; вартістю навчання, яка щороку зростає, при одночасному скороченні державних видатків.

Посилення економічної потужності великих міст та мегаполісів, перетворення них на основні центри робочих місць створюють до відповідних дисбалансів на регіональному рівні (як на ринку освітніх послуг, так і ринків робочої сили), що актуалізує кластеризацію університетів за галузевим принципом. Слід зазначити, що вітове господарство швидко урбанізується, що посилює попит на вищу освіту. Ця тенденція притаманна не тільки розвинутим країнам, а й тим, що розвиваються. Особливо швидкими темпами урбанізація просувається в Китаї, Індії, країнах Латинської Америки.

Понад $55 \%$ світового населення (4,2 мільярда у 2018 році) мешкає у містах. За прогнозними очікуваннями ООН к 2030 року цей показник зросте до 60,4\%, а к 2050 року - до $68,4 \%$ причому основна частина цього збільшення (близько 90\%) відбувається в Азії та Африці . Прогнозується, що до 2050 року Індія додасть 416 млн. міських жителів, Китай - 255 млн., Нігерія - 189 млн., що разом становитиме 35\% від прогнозованого приросту міського населення світу. В європейських міських районах буде сконцентровано 83,7\%, північноамериканських - 89,0\% ..

Університети розширюють перелік освітніх послуг, залучаючи до вищої освіти нетрадиційних за віком студентів (понад 24 роки), кількість яких буде щороку тільки зростати. Зростання тривалості життя, підвищення пенсійного віку, все більше актуалізують проблему навчання потягом всього життя, спроможного надавати нові навички, потрібні для нових умов праці. А від так, кількість нетрадиційних за віком студентів буде тільки зростати і залежатиме від специфіки та традицій кожної країни. Так, у Європейському Союзі рівень участі дорослих в освітніх програмах протягом чотирьох тижнів $є$ достатньо незмінним - за останні десять років відсоток доросли, що 
Актуальні проблеми розвитку економіки регіону. Вип 16. T.2

задіяні у навчанні зріз з 9,5\% у 2008 році до 10,9\% у 2017 році. У той же час, в Італії цей показник зріс на 25,4 \%, у Швеції - на 35,1\%, тоді як у Великобританії, навпаки скоротився з 20,5\% до 14,3\% за цей же період (рис..1)



Puc.1. Навчання дорослих у Європейському Союзі та окремих європейських країнах [15]

Fig.1. Adult education in the European Union and some European countries

Збільшення кількості нетрадиційних за віком здобувачів вищої освіти вимагають від університетів розвивати нові технологій навчання (масові відкриті онлайн курси, дистанційні технології тощо), посилювати творчу складову у навчальних планах підготовки. Так, до 2030 року в 15 країнах з високим рівнем доходу буде більше 4,3 мільйонів студентів будуть навчатися студенти у віці старше 24 років, основна частина яких буде припадати на Китай та Індію [8].

Слід зауважити, що у країнах ОЕСР особи, що мають 3 іммігрантське походження 3 меншою вірогідністю братимуть участь у освітніх програмах [8], оскільки іммігранти першого та другого покоління недостатньо представлені серед абітурієнтів і випускників бакалаврських програм. Аналогічно, рівень зайнятості серед дорослих, які здобули вищу освіту, серед іноземних виявився також нижчим, порівняно із іншими категоріями робітників. У той же час, результати дослідження свідчать, що рівень інтенсивності міграції із зростанням освіти тільки збільшується (рис.2.).Якщо питома вага іноземних студентів, що вступають до вищої школи, становить $6 \%$ від загальної кількості студентів, то вже на докторські програми вступає 26\% студентів-іноземців від загальної кількості аспірантів [8, с.218]. 


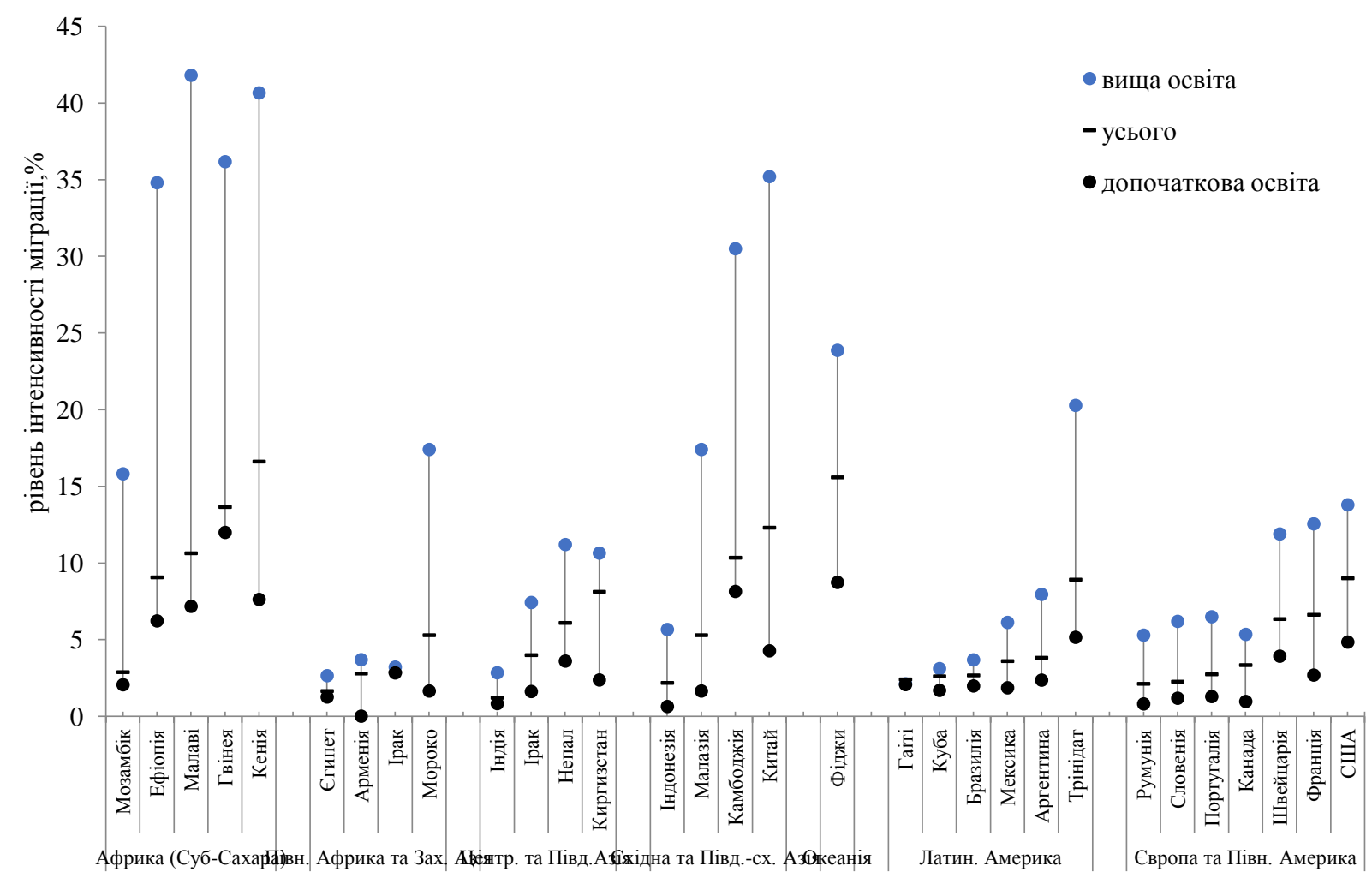

Рис. 2. Рівень інтенсивності міграції за освітою за окремими країнами

Fig. 2. The level of intensity of migration by education in individual countries

Країни із ринками, що розвиваються сьогодні активно залучаються до вищої освіти, інвестують у кращі освітні ресурси, розвиток академічної мобільності. Важливою мотивацією цього $є$ те, що випускники із науковим степенем мають можливість отримати більш високу заробітню плату. Середній розмір заробітної плати тих, хто має вищу освіту, є значно вищим. Однак, якщо для ЄС та США рівень заробітної плати тих, хто має ступінь бакалавра, магістра на 60-75\% є вищим, то для країн, що мають середній або низький рівень доходу, цей показник вище в 1,5 рази [8], тому, для мешканців країн, що розвиваються, цінність вищої освіти є значно вищою.

Практично за усіма прогнозними оцінками різноманітних міжнародних інституцій, дослідницьких груп, агенцій тощо кількість іноземних студентів буде щороку зростати, більшість яких буде обирати для отримання вищої освіти розвинуті країни. Відповідно, університети, національні уряди країн будуть спрямовувати свої зусилля на пошук нових шляхів та механізмів залучення на навчання іноземних студентів, у тому числі використовуючи інструменти міграційної політики.

Збільшення кількості бажаючих отримати вищої освіти, у першу чергу, в країнах із низьким та середнім рівнем доходу, відповідно, посилюють попит, при цьому кількість університетів у країнах із високим рівнем доходу суттєво не змінюється. Відповідно, університети цих країн стають більш залежними саме від кількості студентів з менш розвинутих країн. Слід підкреслити, що вартість вищої освіти зростає значно вищими темпами, випереджаючи інфляцію цін на споживчі товари, медичні витрати, продовольчі товари тощо. Так за даними агентства Bloomberg, в США вартість навчання у середньому за останні 40 років зросла в 12 разів, тоді як витрати на медичні послуги зросли на $601 \%$, а ціни на продукти харчування зросли на $244 \%$ за той же період [17]. Відповідно, зростаюча вартість робіть університети менш доступними, що вимагає додаткових зусиль з боку вищів щодо розвитку пропозиція більш якісних 
програм, що роблять більш конкурентоспроможними випускників університетів на ринку.

У світовому господарстві відбуваються зміни, які впливають на поширення цифрової економіки [21, с.7-9]. Ці зміни пов'язані із переходом від аналогового до цифрового зв'язку, значна частина трансакцій сьогодні відбувається в інтернеті (передача інформації, робота 3МІ тощо), доступ до якого у світі в цілому зріс за останні десять років на 65\%[11]. Рівень розвитку мобільних технологій зв'язку дозволяють підключення до цифрових мереж у будь-який момент часу, шляхом використання смартфонів, планшетів, ноутбуків тощо. При цьому, людина обирає бажаний для себе потік інформації, який поступає на особисті пристрої. Одночасно, сучасна людина отримала можливість споживаючі цифрові послуги, створювати власні (ведення власних блогів, викладення відеороликів в YоuTube, надання інформації до Wikipedia тощо). Фактично, можна визначити, що відкритість в інтернеті вже практично стала нормою, а сам інтернет став глобальною мережею інформації та ідей. Подібні трансформації, що відбуваються у світі, вимагають змін у навчанні. Одночасно, варто підкреслити, що інтенсивне використання інтернету автоматично не покращує результати та якість навчання, більш того, освіта вже відстала від кривої оцифровування [27].

У світі поширюються різноманітті онлайн форми (online programme management) співпраці із університетами, які надають відповідний освітній контент, а компаніяменеджер забезпечує просування освітніх послуг на онлайн ринку, створюючи нові мобільні та гнучкі пропозиції для студентів. Запуск онлайнової програми є витратним (за різними оцінками 5-10 млн.дол. від етапу проектування та розробки до того моменту, коли програма зможе приносити прибуток). Співпрацюючи із університетами управлінські онлайн платформи пропонують покриття цих витрат і отримують частину доходів від навчання. Американські університети стрімко розвивають свої онлайн-програми. За даними дослідницької компанії Eduventures[19] близько 12\% університетів США - або 350 установ - сьогодні активно розвивають сегмент онлайн освіти. До 2020 року їх кількість зросте до 500, а сам ринок онлайн освіти становитиме 2,5 млрд.дол. Лідерами на цьому ринку онлайн освіти $є \underline{2 \mathrm{U}}$, Coursera, ExecOnline, Orbis Education та інші потужні системи діджитал освіти, що реалізують онлайн-програми спільно із багатьма провідними університетами світу.

За результатами дослідження розвитку онлайн освіти в університетах США, яке проведене дослідницькою групою Babson Survey Research, виявлено, щорічне зростання кількості студентів, що опановують онлайн освіту, становить 3,9\% [7]. Загальна кількість таких студентів становить понад 6 млн.осіб, з яких 3,1 млн.осіб вивчають окремі дистанційні курси, а 2,9 млн.осіб безпосередньо отримують дистанційну освіту. Переважна кількість студентів (майже 5 млн.осіб) опановують програми бакалаврату. У розвитку дистанційної освіти домінуючу роль відіграють програми, що контролюються державними установами. Однак більший рівень щорічного зростання демонструє приватний сектор, які у майбутньому можуть стати ключовими гравцями у наданні дистанційної освіти.

Технології електронного навчання змінюють реальність, створюючи [4]: доповнену реальність (додає до пізнання світу), віртуальну реальність (замінює реальний світ), і змішану реальність (додає віртуальні елементи до реального світу). Використовуючи сучасні відкриті онлайн системи викладачі активно розвивають відкриту педагогіку, залучаючи студентів до навчального процесу, отримуючи інформацію від них. За допомогою відкритої педагогіки викладачі можуть використовувати відкриті технології, щоб допомогти спростити навчальний процес. Й 
нарешті, цифрові технологій змінюють механізми фінансування вищої освіти (блокчейн).

Висновки. Основними зрушеннями, що відбуваються у глобальному освітньому просторі в сучасних умовах визначено наступні. По-перше, слід відзначити взаємозв'язок трансформації, що відбуваються на ринку праці, і з якими пов'язані зміни у системі вищої освіти. Спостерігається зростання попиту на ринку вищої освіти при збереженні існуючої численності університетів. Зростання автоматизації неминуче впливає на зміни ринку праці. Одночасно, значною проблемою залишається поглиблення розриву між вимогами роботодавців та університетським досвідом. Подруге, відбуваються зміни у фінансуванні освіти, спостерігається скорочення державних джерел фінансування діяльності університетів. По-третє, суттєвих змін зазнає і «віковий ценз» здобувачів освіти, оскільки збільшення кількості нетрадиційних здобувачів вищої освіти, вік яких старше 24 років. Подовження середньої тривалості життя посилює вплив на розвиток системи освіти дорослих, можливостей підвищення кваліфікації та перекваліфікації. По-четверте, слід відзначити інтенсифікацію мобільності студентів, яка зумовлена не тільки розвитком комунікацій у світі, а й 3 посиленням економічної потужності великих міст, до яких спрямовуються основні потоки студентів. Значний вплив забезпечують економічні зрушення у системі вищої освіти, посилення ролі країн, що розвиваються, у тому числі і у формуванні середнього класу. Від так, посилиться боротьба університетів щодо їх намагання залучити найкращих студентів. Одночасно, нерівність можливостей різних соціальних класів може негативно вплинути на посилення диспропорцій. По-п’яте, розвиток цифровізації освіти впливає не тільки на формування нових можливостей у впровадженні новітніх технологій освітньої діяльності. Зазначені зрушення пов'язані із тенденціями, що враховують як внутрішні трансформації, так і глобальні зміни, і які визначатимуть характер розвитку інтернаціоналізації вищої освіти, розвиток університетів, національних стратегій розвитку вищої освіти тощо.

1. Adams M. Global Trends in Higher Education. Center for Global Studies URL: http://publish.illinois.edu/globalcurrents/2019/02/20/global-trends-in-higher-education/ _ (дата звернення: 20.10.2020)

2. Altbach P. G. Comparative perspectives in higher education for the twenty-first century. Higher Education Policy. 1998. Vol. 11. Issue 4. P. 347-356.

3. Altbach P. G., Reisberg L., Rumbley L. E. Trends in global higher education: Tracking an academic revolution. Chestnut Hill, MA: Boston College Center for International Higher Education, 2009. URL:

http://www.cep.edu.rs/public/Altbach,_Reisberg,_Rumbley_Tracking_an_Academic_Revolution,_UN ESCO_2009.pdf. (дата звернення: 20.10.2020)

4. Bishop J. Three eLearning and Higher Education Trends for 2019 . URL: https://modelelearning.com/2019/01/01/three-elearning-and-higher-education-trends-for-2019/ (дата звернення: 20.10.2020)

5. Chatlani S. 8 global trends impacting higher education. URL://https://www.educationdive.com/news/8-global-trends-impacting-higher-ed/515272/_ (дата звернення: 20.10.2020)

6. Delanty G. Challenging knowledge: the university in the knowledge society. Open University Press, Buckingham. 2001. 175p.

7. Digital Learning Compass. Distance Education Enrollment / I. Elaine Allen, Jeff Seaman, Babson Survey Research Group, 2017. 36p.

8. Education at a Glance: OECD Indicators, OECD Publishing, Paris.2018.462p. URL: http://dx.doi.org/10.1787/eag-2018-en

9. Education indicators focus. How is the global talent pool changing (2013, 2030). OECD.2015 URL: https://www.oecd.org/education/EDIF\%2031\%20(2015)--ENG--Final.pdf. (дата звернення: 20.10.2020) 


\section{Актуальні проблеми розвитку економіки регіону. Вип 16. T.2}

10. Egron-Polak E., Hudson R. Internationalization of Higher Education: Growing expectations, fundamental values: IAU 4th Global Survey. International Association of Universities. 2014. 146p.

11. Global Trends in Higher Education and geographic perspectives for the T.I.M.E. Top International Managers in Enginiring Association. Assembly. URL:http://www.time-association.org/wp-content/uploads/2017/12/TIME_Geographic_DEVELOPM ENT.pdf. (дата звернення: 20.10.2020)

12. Bulatova O., Zaykovskyi O. International student mobility: current trends and influence factors. Research Papers in Economics and Finance. Poznań University of Economics and Business, 2020. Issue 2. P.19-27

13. Internationalisation of higher education. Study. European Parliament's Committee on Culture and Education. Brussels, 2015. 321p. URL: http://www.europarl.europa.eu/RegData/etudes/STUD/2015/540370/IPOL_STU(2 015)540370_EN.pdf (дата звернення: 20.10.2020)

14. Jamrisko M. Cost of College Degree in U.S. Soars 12 Fold: Chart of the Day/ Michelle Jamrisko and Ilan Kolet . URL: https://www.bloomberg.com/news/articles/2012-08-15/cost-of-college-degree-in-u-ssoars-12-fold-chart-of-the-day(дата звернення: 20.10.2020)

15. Global Education Monitoring Report. URL: http:/gem-report-2019.unesco.org/graphics/figures/(дата звернення: 20.10.2020)

16. Kalil T. Jahanian F. Computer Science is for Everyone! URL: https://obamawhitehouse.archives.gov/blog/2013/12/11/computer-science-everyone(дата звернення: 20.10.2020)

17. Kharas H. The Unprecedented Expansion Of The Global Middle Classof The Global Middle Class An Update. Global Economy \& Development WorkingPaper100, 2017.32p. URL:https://www.brookings.edu/wp-content/uploads/2017/02/global_2 0170228_global-middle-class.pdf (дата звернення: 20.10.2020)

18. Knight J., Wit H. Internationalization of Higher Education: Past and Future. International Higher Education, 2018. № 95. P.2-4

19. Market News Bulletin: 24th October - 6 Th November 2015/ Compiled by Jamie Aston. Market Intelligence for University Worldwide. 63p.

20. McMahon W. The Total Return to Higher Education: Is There Underinvestment for Economic Growth and Development? URL:https:/uofi.app.box.com/s/wo76gs4reryzdn4epgae/file/295611470745 (дата звернення: 20.10.2020)

21. Online \& Blended Learning: Selections From The Field/ Jill Buban, Thomas B. Cavanaugh, Charles D. Dziuban, Charles R. Graham, Susan Ko, Patsy D. Moskal, Michelle Pacanksy-Brock, Anthony G. Picciano, Steve Rossen, Jared Stein, Robert Ubell Routledge. Taylor and Francis Group. 133p

22. Rhoades, G. Backlash Against “Others”. International Higher Education, (89), 2-3. URL: https://doi.org/10.6017/ihe.2017.89.9830 (дата звернення: 20.10.2020)

23. Science \& Engineering Indicators 2018.URL:https://www.nsf.gov/statistics/2018/nsb20181/(дата звернення: 20.10.2020)

24. Scott P. Massification, Internationalization and Globalisation.The Globalization of Higher Education. Buckingham: SRHE and Open University Press, 1998. P. 108-129.

25. Teichler U. Internationalisation Trends in Higher Education and the Changing Role of International Student Mobility. Journal of international Mobility, 2017/1. № 5. P.177216. URL:https://www.cairn.info/revue-journal-of-international-mobility-2017-1-page-

177.htm?try_download=1\# ((дата звернення: 20.10.2020)

26. Total separations levels and rates by industry and region, seasonally adjusted. Economic News Release URL:https://www.bls.gov/news.release/jolts.t03.htm (дата звернення: 20.10.2020)

27. Trend Shaping Education 2019. OECD publishing. URL: https://read.oecdilibrary.org/education/trends-shaping-education-2019_trends_edu-2019-en\#page1(дата звернення: 20.10.2020)

28. Trends In Higher $2019 . \quad$ Hanover $\quad$ Research URL:https://cdn2.hubspot.net/hubfs/3409306/Hanover-Research-Higher-Ed-Trend-Report-2019.pdf (дата звернення: 20.10.2020)

29. World Economic Situation and Prospects Monthly Briefing Economic Analysis and Policy Division. Department of Economic and Social Affairs. United Nations. 1 April 2019. URL: http://www.bit.ly/wespbrief. (дата звернення: 20.10.2020)

30. Булатова О. В., Зайковський О. С. Глобалізація освітнього простору: основні характеристики та принципи розвитку. Вісник Маріупольського державного університету. Серія: Економіка.2019. Вип. 17. С. 63-71. 
31. Оцінка рівня розвитку процесів інтернаціоналізації національних систем вищої освіти на основі використання багатовимірних показників О.В.Булатова, О.С. Зайковський. Науковий вісник Ужгородського національного університету. Серія: Міжнародні економічні відносини та світове господарство. 2019. Вип. 28/2019, Ч.1. С.69-75.

\section{References}

1. Adams, "Global Trends in Higher Education." Publish.illinois, publish.illinois.edu/globalcurrents/2019/02/20/global-trends-in-higher-education/ Accessed 20 Oct. 2020.

2. Altbach, P. G. "Comparative perspectives in higher education for the twenty-first century." Higher Education Policy, vol. 11, issue 4, 1998, pp. 347-356.

3. Altbach, P. G., Reisberg, L., and L. E. Rumbley. Trends in global higher education: Tracking an academic revolution. Chestnut Hill, MA, Boston College Center for International Higher Education, 2009,

www.cep.edu.rs/public/Altbach,_Reisberg,_Rumbley_Tracking_an_Academic_Revolution,_UNESC O_2009.pdf. Accessed 20 Oct. 2020.

4. Bishop, J. "Three eLearning and Higher Education Trends for 2019." Modelelearning, modelelearning.com/2019/01/01/three-elearning-and-higher-education-trends-for-2019/ Accessed 20 Oct. 2020.

5. Chatlani, S. "8 global trends impacting higher education." Educationdive, www.educationdive.com/news/8-global-trends-impacting-higher-ed/515272/ Accessed 20 Oct. 2020.

6. Delanty, G. Challenging knowledge: the university in the knowledge society. Open University Press, Buckingham. 2001. 175p.

7. Allen, I. Elaine, and Jeff Seaman. Digital Learning Compass. Distance Education Enrollment, 2017.

8. Education at a Glance: OECD Indicators. Paris, OECD Publishing, 2018. doi.org/10.1787/eag-2018en

9. Education indicators focus. How is the global talent pool changing (2013, 2030). OECD.2015, www.oecd.org/education/EDIF\%2031\%20(2015)--ENG--Final.pdf. Accessed 20 Oct. 2020.

10. Egron-Polak, E., and R. Hudson. Internationalization of Higher Education: Growing expectations, fundamental values: IAU 4th Global Survey. International Association of Universities. 2014.

11. "Global Trends in Higher Education and geographic perspectives for the T.I.M.E.” Top International Managers in Enginiring Association. General Assembly, www.time-association.org/wp-content/uploads/2017/12/TIME_Geographic_DEVELOPMENT.pdf. Accessed 20 Oct. 2020.

12. Bulatova O., and O. Zaykovskyi. "International student mobility: current trends and influence factors.” Research Papers in Economics and Finance, issue 2, 2020, pp.19-27.

13. "Internationalisation of higher education. Study." European Parliament's Committee on Culture and Education. Brussels, 2015, www.europarl.europa.eu/RegData/etudes/STUD/2015/540370/IPOL_STU(2015)540370_EN.pdf Acc essed 20 Oct. 2020.

14. Jamrisko, M., and I. Kolet . "Cost of College Degree in U.S. Soars 12 Fold: Chart of the Day.” Bloomberg, www.bloomberg.com/news/articles/2012-08-15/cost-of-college-degree-in-u-s-soars-12-fold-chart-ofthe-day. Accessed 20 Oct. 2020.

15. “Global Education Monitoring Report.” gem-report-2019.unesco.org/graphics/figures/ Accessed 20 Oct. 2020.

16. Kalil, T., and F. Jahanian. "Science is for Everyone!" Obamawhitehouse, obamawhitehouse.archives.gov/blog/2013/12/11/computer-science-everyone. Accessed 20 Oct. 2020.

17. Kharas, H. "The Unprecedented Expansion Of The Global Middle Classof The Global Middle Class An Update.” Global Economy \& Development WorkingPaper, 2017. Brookings, www.brookings.edu/wp-content/uploads/2017/02/global_20170228_global-middle-class.pdf. Accessed 20 Oct. 2020.

18. Knight J., and H. "Wit Internationalization of Higher Education: Past and Future." International Higher Education, no. 95, 2018, pp.2-4

19. Market News Bulletin: 24th October - 6 Th November 2015. Compiled by Jamie Aston. Market Intelligence for University Worldwide.

20. McMahon, W. "The Total Return to Higher Education: Is There Underinvestment for Economic Growth and Development?” uofi.app.box, uofi.app.box.com/s/wo76gs4reryzdn4epgae/file/295611470745. Accessed 20 Oct. 2020.

21. Online \& Blended Learning: Selections From The Field/ Jill Buban, Thomas B. Cavanaugh, Charles D. Dziuban, Charles R. Graham, Susan Ko, Patsy D. Moskal, Michelle Pacanksy-Brock, Anthony G. Picciano, Steve Rossen, Jared Stein, Robert Ubell Routledge. Taylor and Francis Group. 
Актуальні проблеми розвитку економіки регіону. Вип 16. T.2

22. Rhoades, G. "Backlash Against “Others”. International Higher Education, (89), 2-3. doi.org/10.6017/ihe.2017.89.9830. Accessed 20 Oct. 2020.

23. “Science \& Engineering Indicators 2018.” nsf, www.nsf.gov/statistics/2018/nsb20181/ Accessed 20 Oct. 2020.

24. Scott, P. Massification, Internationalization and Globalisation.The Globalization of Higher Education. Buckingham, SRHE and Open University Press, 1998. pp. 108-129.

25. Teichler, U. "Internationalisation Trends in Higher Education and the Changing Role of International Student Mobility.” Journal of international Mobility, no, 5, 2017/1, pp .177-216. cairn.info, www.cairn.info/revue-journal-of-international-mobility-2017-1-page-177.htm?try_download=1\# Accessed 20 Oct. 2020.

26. "Total separations levels and rates by industry and region, seasonally adjusted."Economic News Release. bls, www.bls.gov/news.release/jolts.t03.htm. Accessed 20 Oct. 2020.

27. "Trend Shaping Education 2019. OECD publishing." read.oecd-ilibrary, read.oecdilibrary.org/education/trends-shaping-education-2019_trends_edu-2019-en\#page1. Accessed 20 Oct. 2020.

28. “Trends In Higher Education: 2019.” Hanover Research, cdn2.hubspot.net/hubfs/3409306/HanoverResearch-Higher-Ed-Trend-Report-2019.pdf Accessed 20 Oct. 2020.

29. "World Economic Situation and Prospects Monthly Briefing Economic Analysis and Policy Division.” Department of Economic and Social Affairs. United Nations. 1 April 2019, www.bit.ly/wespbrief. Accessed 20 Oct. 2020.

30. Bulatova, O.V., and O.S.Zaikovsky. "Estimation Of Development Level Of The National Higher Education System Internationalization Processes On The Basis Of Multidimensional Indicators." Uzhgorod University Scientific Bulletin. Series: Economics and international economic relation, no. 1(3), 2019, pp. 43-51.

31. Bulatova, O.V., and O.S.Zaikovsky. "Globalization of the educational space: basic characteristics and principles of development.” Bulletin of Mariupol State University. Series: Economics, vol.17, 2019, pp. 63-71, visnyk-ekonomics.mdu.in.ua/ARHIV-uk/17/10.pdf. Accessed 20 Oct. 2020. 